\title{
Ethanolic extract of Nymphaea lotus L. (Nymphaeaceae) leaves exhibits in vitro antioxidant, in vivo anti-inflammatory and cytotoxic activities on Jurkat and MCF-7 cancer cell lines
}

\author{
Benoit Banga N'guessan ${ }^{1 *}$ (D), Adwoa Dede Asiamah', Nana Kwame Arthur', Samuel Frimpong-Manso², \\ Patrick Amoateng', Seth Kwabena Amponsah', Kennedy Edem Kukuia', Joseph Adusei Sarkodie', \\ Kwabena Frimpong-Manso Opuni ${ }^{2}$, Isaac Julius Asiedu-Gyekye ${ }^{1}$ and Regina Appiah-Opong ${ }^{4}$
}

\begin{abstract}
Background: Nymphaea lotus L. (N. lotus) is an aquatic plant with anecdotal reports suggesting its use in the traditional management of cancer. However, there is a paucity of data on the antioxidant, anti-inflammatory and cytotoxic properties of $\mathrm{N}$. lotus in relation to its phytochemical and elemental contents. This study aimed at determining the antioxidant, anti-inflammatory and cytotoxic properties of the hydro-ethanolic extract of $\mathrm{N}$. lotus leaves (NLE), and its phenolic, flavonoid and elemental constituents.

Methods: The antioxidant property of NLE was determined using total phenolic and flavonoid, DPPH radical scavenging, lipid peroxidation and reducing power assays. The anti-inflammatory activity of NLE (100-250-500 mg/ $\mathrm{kg}$ ), diclofenac and hydrocortisone (positive controls) were determined by paw oedema and skin prick tests in Sprague Dawley rats. Also, the erythrocyte sedimentation rate (ESR) was determined by Westergren method. The macro/micro-elements content was determined by the XRF method. The cytotoxic property of NLE was determined by the MTT assay, on two cancer cell lines (MCF-7 and Jurkat) and compared to a normal cell line (Chang liver). Inhibitory concentrations were determined as $\mathrm{IC}_{50}$ values ( \pm SEM).

(Continued on next page)
\end{abstract}

\footnotetext{
*Correspondence: bbnguessan@ug.edu.gh; benoitnquessan@yahoo.com 'Department of Pharmacology and Toxicology, School of Pharmacy, College of Health Sciences, University of Ghana, P.O. Box LG 43, Legon, Accra, Ghana Full list of author information is available at the end of the article
}

(c) The Author(s). 2021 Open Access This article is licensed under a Creative Commons Attribution 4.0 International License, which permits use, sharing, adaptation, distribution and reproduction in any medium or format, as long as you give appropriate credit to the original author(s) and the source, provide a link to the Creative Commons licence, and indicate if changes were made. The images or other third party material in this article are included in the article's Creative Commons licence, unless indicated otherwise in a credit line to the material. If material is not included in the article's Creative Commons licence and your intended use is not permitted by statutory regulation or exceeds the permitted use, you will need to obtain permission directly from the copyright holder. To view a copy of this licence, visit http://creativecommons.org/licenses/by/4.0/ The Creative Commons Public Domain Dedication waiver (http://creativecommons.org/publicdomain/zero/1.0/) applies to the data made available in this article, unless otherwise stated in a credit line to the data. 
(Continued from previous page)

Results: The extract had appreciable levels of phenolic and flavonoids compounds and was two-fold more potent in scavenging DPPH radicals than Butylated hydroxytoluene (BHT). However, NLE was three- and six-fold less potent than ascorbic acid and BHT, respectively, in reducing $\mathrm{Fe}^{3+}$ to $\mathrm{Fe}^{2+}$. The extract was six-fold more potent than gallic acid in inhibiting lipid peroxidation. The extract caused a dose-dependent decrease in rat paw oedema sizes, comparable to diclofenac, and a significant decrease in wheel diameters and ESR. The elemental analysis revealed relevant concentrations of $\mathrm{Mg}^{2+}, \mathrm{P}^{2+}, \mathrm{S}^{2+}, \mathrm{K}^{2+}, \mathrm{Mn}^{+}, \mathrm{Fe}^{+}, \mathrm{Cu}^{+}, \mathrm{Zn}^{+}$and $\mathrm{Cd}^{+}$. The extract exhibited cytotoxic activity on both MCF-7 $\left(I C_{50}=155.00 \mu \mathrm{g} / \mathrm{ml}\right)$ and Jurkat $\left(I C_{50}=87.29 \mu \mathrm{g} / \mathrm{ml}\right)$, with higher selectivity for Jurkat cell line. Interestingly, the extract showed low cytotoxicity to the normal Chang liver cell line $\left(\mathrm{IC}_{50}=204.20 \mu \mathrm{g} / \mathrm{ml}\right)$.

Conclusion: N. lotus leaves extract exhibited high antioxidant, anti-inflammatory and cancer-cell-specific cytotoxic properties. These aforementioned activities could be attributed to its phenolic, flavonoid and elemental constituents.

Keywords: Nymphaea lotus, Cytotoxicity, Micro/macro-elements, MCF7, Jurkat

\section{Background}

Non-communicable diseases (NCDs) such as cardiomyopathies, chronic respiratory diseases, diabetes, and cancer are among the commonest causes of mortality and morbidity worldwide. In sub-Saharan-Africa, NCDs represent a significant cause of death and disability. NCDs are predicted to surpass infectious diseases as the most important cause of morbidity and mortality by 2030 [13]. Oxidative stress (OS) and inflammation are primary molecular mechanisms that play critical roles in the onset and development of NCDs [4,5]. Understanding the role of OS and inflammation in NCDs has paved way for the discovery of novel compounds with high antioxidant and anti-inflammatory potential, that can be used in the management of NCDs and cancer in particular.

Cancer is reported to be the second leading cause of death worldwide, with an estimated 9.6 million deaths in $2018[6,7]$. This estimation has been projected to double by the next coming decade despite therapeutic advances made in recent years and the improvement in the management of cancer patients [7, 8]. It is noteworthy, that, nearly $70 \%$ of these cancer-related deaths happen in low- and middle-income countries (https://www.who. $\mathrm{int} /$ news-room/fact-sheets/detail/cancer). According to the New Global Cancer Data [6], Africa has the highest proportion of cancer deaths compared with its incidence, and this is likely due to the high occurrence of cancer types related to poor prognosis along with restricted access to timely diagnosis and treatment [9]. Examples of common and/or neglected cancers are breast cancer and leukaemia.

Breast cancer is a common invasive cancer found in females. Data suggests that prevalence of breast cancer is on the increase among Ghanaian women, unlike in North American women [10, 11]. Currently, a surrogate classification of five subtypes of breast cancer (based on histological and molecular characteristics) is being used in clinical practice. Tumours expressing progesterone receptor (PR) and/or estrogen receptor (ER) are considered hormone receptor-positive breast cancers, while in triple-negative breast cancer (TNBC), tumours do not express any of these receptors. Just as in the rest of the world, invasive ductal carcinoma is the commonest histological type of breast cancer in Africa [12, 13]. Acute T-cell leukemia (ALT) exhibits a very invasive pattern of progression associated with a reduced overall survival due to factors such as chemoresistance and immunosuppression $[14,15]$. Due to high mortality associated with the aforementioned cancers, there is the need for agents with high efficacy (and few adverse effects) to help in managing these conditions.

During the past 18 years, cancer treatment strategies have markedly shifted from the use of cellularly-targeted therapies to the elaboration of molecularly-targeted drugs. However, using a single molecularly-targeted agent would often not yield good clinical response. Therefore, the use of combination therapy targeting multiple molecular sites could be of benefit in managing cancers [16]. Medicinal plants used to manage cancers traditionally have been shown to possess different properties such as antioxidant, anti-inflammatory, cytotoxic, immunostimulant, anti-bleeding, providing minerals, vitamins, enzymes, and micronutrients to the body, etc. $[17,18]$. Therefore, the use of medicinal plant (that are combinations of active phytochemicals, micro and macro elements) with established and promising antioxidant, anti-inflammatory and cytotoxic potentials could represent an alternative to conventional cancer chemotherapy in Africa [19].

Although questioned by some authors [20], it is generally reported in the literature that up to $80 \%$ of the population in Africa depend on traditional medicines for their primary healthcare needs [21]. In Ghana, there have been efforts to integrate herbal medicines into the conventional health care system [22]. The interest for herbal products is also on the rise even in developed 
countries such as the United States of America, where approximately $20 \%$ of people use herbal products for various health conditions [23]. However, many phytotherapies remain poorly studied.

Nymphaea lotus L. (N. lotus), from the family Nymphaeaceae (water lily family), is a perennial aquatic flowering plant. It is native to Egypt and grows in various parts of Central Africa, West Africa, and Madagascar $[24,25] . N$. lotus is known to possess numerous ethnomedicinal properties and often used in the treatment of rheumatic pains, tumours and cancers [26-30]. Reports of phytochemical analysis showed that the major bioactive metabolites in Nymphaea species are flavonoids and phenolic compounds, and that $N$. lotus contains very special macrocyclic flavonoids [31, 32]. Based on earlier studies, one can say that $N$. lotus would be a good source of new isolates with high antioxidant, antiinflammatory and cytotoxic potentials.

Secondary metabolites found in plants that have been shown to be pharmacologically active include flavonoids, alkaloids, tannins, glycosides and sugars, among others [33]. Interaction between secondary metabolites and micro and macro elements in plants are known to either decrease or enhance bioavailability of these secondary metabolites [34]. Conversely, toxic heavy metals that are environmental pollutant from the soil, water or air can be absorbed by medicinal plants at high concentrations, and this could partly explain reported toxic effects of some plants [35]. The World Health Organization therefore recommends systemic determination of heavy metal content and maximum permissible levels of some heavy metals (cadmium, arsenic, and lead) in raw consumable plant materials [36].

The aim of the current study was to determine the invitro antioxidant potential, in-vivo anti-inflammatory activity and the cytotoxic property of the hydro-ethanolic extract of the leaves of $N$. lotus on Jurkat (leukaemia) and MCF7 (breast cancer) cell lines, and Chang liver (normal) cell line. Also, this study sought to determine and relate the total phenol, total flavonoid and the macro/micro-elemental constituents of the leaves of $N$. lotus to its pharmacological activities.

\section{Methods}

\section{Plant collection and extraction}

The plant, $N$. lotus, was collected, following the local legislation, in August 2015 from the wild in Koumassi (Latitude: $5^{\circ} 16^{\prime} 60.00^{\prime \prime} \mathrm{N}$; Longitude: $-3^{\circ} 58^{\prime} 59.99^{\prime \prime} \mathrm{W}$ ), a suburb of Abidjan (Cote d'Ivoire). No permission was required to collect these plants. The plant was identified by Mr. Digbeu Luc Gouda (a herbalist) and authenticated by Dr. Cindy Kitcher at the Department of Pharmacognosy and Herbal Medicine (School of Pharmacy, University of Ghana), where a voucher specimen was placed (voucher number $\mathrm{PH} / 2015 / 001$ ). Plant extraction was performed as previously described [37], with slight modification. Briefly, the fresh leaves of $N$. lotus were separated from the other parts of the plant, dried at room temperature for 2 weeks and then ground into a powder. The powder was then dried again in an incubator at $45^{\circ} \mathrm{C}$ for $36 \mathrm{~h}$. A mass of $157.5 \mathrm{~g}$ of the powdered plant was weighed and dissolved in $20: 80 \mathrm{~V} / \mathrm{v}$ of water and ethanol. Dissolution was in the ratio 1:10 (1 part of powder to 10 parts of solvent). The mixture was macerated with intermittent stirring for $24 \mathrm{~h}$ and filtered. Filtrates were pulled together and concentrated using a rotary evaporator (Rotavapor, Switzerland) at $40^{\circ} \mathrm{C}$. The resulting concentrate was freeze-dried. The powder obtained (referred to as NLE) was kept in an air-tight container and stored at room temperature.

\section{Phytochemical screening}

Tests for the presence of phytochemicals (triterpenoids, saponins, flavonoids, tannins, phenolic compounds and alkaloids) contained in the NLE extract were conducted according to protocols previously reported [38].

\section{Total flavonoid content assay}

The total flavonoid content of NLE extract was determined as previously described [39]. Briefly, a mass of $100 \mu \mathrm{g}$ of different concentration of NLE extract was placed in a 96 well plate, $2 \%$ aluminium chloride was added to each well and incubated at room temperature. Absorbances were then read at $420 \mathrm{~nm}$. Total flavonoid was evaluated as quercetin equivalent $(\mathrm{mg} / \mathrm{ml})$.

\section{Total phenolic assay (modified Folin-Ciocalteau method)}

The total phenol content of NLE extract was determined as previously described [39]. Briefly, aliquots $(10 \mu \mathrm{l})$ of NLE extract and gallic acid of different concentrations were placed in Eppendorf tubes. Distilled water $(0.79 \mathrm{ml})$ and Folin-cicocalteau reagent $(\sim 50 \mu \mathrm{l})$ were subsequently added and mixed totally. The mixture was afterwards incubated at room temperature for $8 \mathrm{~min}$. After incubation, $\mathrm{Na}_{2} \mathrm{CO}_{3}$ solution $(150 \mu \mathrm{l})$ was added, mixed and again incubated at room temperature for $2 \mathrm{~h}$. Aliquots were put in well-plates, and absorbance read at $750 \mathrm{~nm}$. Triplicates concentrations of NLE and gallic acid prepared were used.

\section{Macro and micro-elements screening: energy dispersive x-ray fluorescence spectroscopic (ED-XRF) measurement} The screening of macro and micro-elements found in $N$. lotus was determined as previously described [40]. Briefly, the powder of $N$. lotus leaves was kept at $60^{\circ} \mathrm{C}$ overnight in an oven before pelletisation and subsequent measurement. Triplicate measured samples ( $4 \mathrm{~g} /$ sample) 
and $0.9 \mathrm{~g}$ of a binder (Fluxana H Elektronic BM-0002-1, Licowax C micro powder PM-Hoechstwax, Germany) were homogenized using the RETSCH Mixer Mill (MM301, Germany) and pressed with a manual hydraulic press (SPECAC, UK) to obtain pellets of $32 \mathrm{~mm}$ in diameter and $3 \mathrm{~mm}$ thickness. These were used for subsequent XRF measurements. The detection limit for light elements $(\mathrm{Si}, \mathrm{Al}, \mathrm{Mg}$ and $\mathrm{Na}$ ) was in the range of 25-50 ppm. For heavy metals, $1-5 \mathrm{ppm}$ was the limit of detection. Calibration was factory done using international rock standards. Simultaneous measurement and analysis of the elemental contents of the samples of $N$. lotus leaves were performed using a SPECTRO X-Lab 2000 spectrometer.

\section{Antioxidant assays}

\section{1,1-diphenyl-2-picryl hydrazyl radical (DPPH) assay}

The DPPH assay was performed as previously described [39]. Briefly, different concentrations of NLE extract were made by threefold serial dilutions starting from an initial concentration of $20 \mathrm{mg} / \mathrm{ml}$. The test samples $(100 \mu \mathrm{L})$ were added in triplicates to $100 \mu \mathrm{L}$ of DPPH in well plates and gently shaken. The plate was covered with a foil and incubated in the dark, at room temperature, for $20 \mathrm{~min}$. Absorbances were then read at $517 \mathrm{~nm}$. The amount of sample required to react with one half of the DPPH was expressed as the relative amount of the positive control, butylated hydroxytoluene (BHT), that reacted. Antioxidant activity of samples was expressed as DPPH radical scavenging by the formula:

$$
\% \text { DPPH radical scavenging }=\frac{\text { Sample absorbance }}{\text { Control absorbance }} \times 100
$$

\section{Lipid peroxidation assay}

The lipid peroxidation assay was performed as previously described [41]. Briefly, $100 \mu \mathrm{L}$ of different concentrations of NLE extract, obtained by twofold dilutions, were added to $1 \mathrm{ml}$ of egg lecithin $[3 \mathrm{mg} / \mathrm{ml}]$ in phosphate buffer. $10 \mu \mathrm{L}$ of $\mathrm{FeCl}_{3}[400 \mathrm{mM}]$ and $10 \mu \mathrm{L}$ of Lascorbic acid [200 $\mathrm{mM}$ ] were then added to induce lipid peroxidation. After incubation for $1 \mathrm{~h}$, at $37^{\circ} \mathrm{C}, 1 \mathrm{ml}$ of $15 \%$ trichloroacetic acid (TCA) and $1 \mathrm{ml}$ of $0.375 \%$ tertbutyl alcohol (TBA) in 20\% acetic acid were added to stop the reaction. The mixture was boiled for $15 \mathrm{~min}$, allowed to cool and centrifuged at $300 \mathrm{~g}$. Absorbance of the supernatant was measured at $532 \mathrm{~nm}$.

\section{Reducing power assay}

The reducing power assay was performed as previously described [42]. Briefly, $200 \mu \mathrm{L}$ of NLE extract were added and mixed to $200 \mu \mathrm{L}$ of potassium ferricyanide. The mixture was incubated at $50{ }^{\circ} \mathrm{C}$ for $20 \mathrm{~min}$, and a volume of $200 \mu \mathrm{L}$ of trichloroacetic acid (TCA) was then added and centrifuged at $300 \mathrm{~g}$ for $10 \mathrm{~min}$. Two hundred (200) $\mu \mathrm{L}$ of the supernatant were pipetted into a tube, and $200 \mu \mathrm{L}$ of distilled water and $40 \mu \mathrm{L}$ of ferric chloride were added. The blank was a solution with all reagents except the NLE. The resulting solution was incubated for $30 \mathrm{~min}$ and pipetted into well plates, after which absorbance was read at $700 \mathrm{~nm}$. Ascorbic acid and BHT were used as positive controls.

\section{Anti-inflammatory assays \\ Animals care and safety}

This research was reviewed and approved by the Ethical and Protocol Review Committee of the College of Health Sciences, University of Ghana (Protocol Identification Number: CHS-Et/M.6-P1.5/2017-2018) and was conducted in accordance with the internationally accepted principles for laboratory animal use and care as found in the US guidelines (NIH publication \#85-23, revised in 1985).

Sixty pathogen-free male Sprague-Dawley rats (Hsd: SD strain), aged 2 to 3 months and weighing $150-200 \mathrm{~g}$, were purchased from the Center for Plant Medicine Research (CPMR), Mampong, Eastern Region, Ghana. Animals were housed in stainless steel cages of 2 cubic feet $(61 \mathrm{~cm} \times 31 \mathrm{~cm} \times 31 \mathrm{~cm})$ with softwood shavings as bedding. They were maintained under standard laboratory conditions (temperature $\sim 25^{\circ} \mathrm{C}$, relative humidity 60 $70 \%$, and $12 \mathrm{~h}$ light-dark cycle), fed with standard pellet diet (AGRIMAT, Kumasi, Ghana) and allowed access to water ad libitum. Animals were acclimatised under these conditions for 7 days before the experiment. To prevent contamination, animals' feeding, and water troughs were washed frequently.

\section{Paw edema test}

The paw edema test was performed as previously described [43]. Briefly, rats were randomly divided into 6 groups of 5 each. Oedema was induced by sub-plantar injection of $100 \mu \mathrm{L}$ of $1 \%$ freshly prepared solution of carrageenan into the right-hind paw of each rat of all groups. Group 1 served as negative control and was administered distilled water; groups 2, 3 and 4 were treated with NLE at 100,250 and $500 \mathrm{mg} / \mathrm{kg}$ of body weight (bw) respectively, 3 days prior to the induction of inflammation. Groups 5 and 6 were given diclofenac $(2 \mathrm{mg} / \mathrm{kg}$ bw) orally and hydrocortisone succinate $(4 \mathrm{mg} / \mathrm{kg} \mathrm{bw})$ intraperitoneally $30 \mathrm{~min}$ before carrageenan injection. Paw thickness was measured just before the carrageenan injection (initial) and then at 1, 2, 3, 4, and $24 \mathrm{~h}$ after carrageenan injection. Increase in paw thickness was measured as the difference in paw thickness at the initial time and paw thickness at respective hours using a plethysmometer. 


\section{Skin prick test and erythrocyte sedimentation rate (ESR)}

The skin prick test was performed, as previously described [44]. Briefly, rats were randomly divided into 6 groups of 5 each and sensitized (group 2, 3, 4, 5 and 6) or not (group 1) by intraperitoneal and subcutaneously injections of albumin (OVA) emulsified in aluminum hydroxide on days 1 and 7. Group 1 (non-sensitized control) and group 2 (OVA-sensitized control) received distilled water orally. In contrast, groups 3,4 and 5 were pre-treated with daily oral administration of NLE extracts $(100,250$ and $500 \mathrm{mg} / \mathrm{kg} \mathrm{bw})$ and group 6 with intraperitoneal administration of hydrocortisone succinate $(4 \mathrm{mg} / \mathrm{kg}$ bw) over 8 days, from day 1 . On day 9 , two separate areas on the skin of all rats were shaved using a blade and the prick test was carried out on all rats by subcutaneous injection of histamine. The time for the appearance of the swelling was noted and the wheal diameters were recorded for all rats at $1 \mathrm{~h}$ and $2 \mathrm{~h}$ after histamine injection. The average skin oedema was calculated for each group and expressed as a percentage of the OVA-sensitized control. Percentage of skin oedema relative to that of OVA-sensitized control for each group was calculated according to the formula:

$\%$ Skin oedema $=\frac{\text { oedema in a particular treated group }}{\text { oedema in sensitized control group }} \times 100$

Rats were then sacrificed by cervical dislocation and the whole blood was collected by cardiac puncture into citrate tubes under sterile conditions. The erythrocyte sedimentation rate was determined as previously described $[45,46]$. Briefly, the Westergren pipette was gently inserted into the citrate tube, and by capillary action, the anticoagulated blood rose to the $0 \mathrm{~mm}$ mark to the top of the pipette. The pipette was placed into a stand and fixed in a vertical position for $1 \mathrm{~h}$. The sedimentation rate was then measured in $\mathrm{mm} / \mathrm{h}$ by reading from the calibrations on the pipette.

\section{In-vitro cytotoxic activity of NLE Cell culture and treatment}

Cell culture and treatment were performed as previously described [47]. Jurkat, MCF-7 and Chang liver cell lines, provided by the Noguchi Memorial Institute for Medical Research, University of Ghana, were cultured in EMEM containing $10 \% \mathrm{FBS}$ and $1 \%$ penicillin/streptomycin and all cells were maintained at $37^{\circ} \mathrm{C}, 100 \%$ relative humidity, $5 \% \mathrm{CO}_{2}, 95 \%$ air, and culture media changed twice a week. The cells were subcultured when they reached $80 \%$ confluence. For the treatment of adherent cells (MCF-7and Chang Liver cells), well plates at a density of $1 \times 10^{4}$ cells/well were seeded with $100 \mu \mathrm{l}$ of cell suspension and incubated for $24 \mathrm{~h}$. The extract concentrations ranged from 62.5 to $1000 \mu \mathrm{g} / \mathrm{ml}$ and curcumin (positive control) from concentrations of 0 to $36.84 \mu \mathrm{M}$ were then added to the cells and incubated for $48 \mathrm{~h}$. For the treatment of suspension cells (Jurkat), $1 \times 10^{4}$ cells/well were seeded and varying concentrations of the extract (62.5 to $1000 \mu \mathrm{g} / \mathrm{ml}$ ) and curcumin ( 0 to $36.84 \mu \mathrm{M})$ were added in the wells. The plates were incubated at $37^{\circ} \mathrm{C}$ in a humidified atmosphere containing $5 \% \mathrm{CO}_{2}$.

\section{MTT assay}

Cytotoxic effects of NLE and curcumin on cell lines were determined using an MTT assay as previously described [47]. Briefly, for adherent cells, after $48 \mathrm{~h}$ of treatment incubation, $15 \mu \mathrm{l}$ of MTT $[5 \mathrm{mg} / \mathrm{ml}]$ in phosphate-buffered saline (PBS) were added and incubated at $37^{\circ} \mathrm{C}$ for $4 \mathrm{~h}$. MTT was flicked off and the formed formazan crystals solubilised in $100 \mu \mathrm{l}$ of DMSO. Absorbance was measured at $570 \mathrm{~nm}$, using a microplate spectrophotometer (Tecan Infinite M200 Pro plate reader, Austria). For suspension cells (Jurkat), after 48-h treatment, the medium was discarded and $20 \mu \mathrm{l} /$ well of MTT solution $[5 \mathrm{mg} / \mathrm{ml}]$ added. The plate was incubated for $3 \mathrm{~h}$ at $37^{\circ} \mathrm{C}$. Finally, $20 \mu \mathrm{l}$ of isopropanol was added to each well and the plate read using a spectrophotometer at a wavelength of $590 \mathrm{~nm}$. The percentage of cell inhibition was determined using the formula:

$$
\% \text { Cell growth inhibition }=100-\left(\frac{\text { Mean absorbance of treated cells }}{\text { Mean absorbance of untreated cells }} \times 100\right)
$$

The experiment was done in triplicate. A graph of mean percentage viability against concentration was plotted, using Graph pad prism 5 and the $\mathrm{IC}_{50} \mathrm{~s}$ of curcumin and the extract (where applicable) were determined.

\section{Statistical analysis}

Percentage inhibition against the log of concentration was plotted for each sample tested, and 50\% inhibitory concentration $\left(\mathrm{IC}_{50}\right)$ interpolated from the curves. $\mathrm{IC}_{50}$ values were determined using Graph Pad Prism software version 5.0 for Windows (GraphPad Software, San Diego, CA, USA) and expressed as $\mathrm{IC}_{50}$ mean value $( \pm$ SEM). Graphs were plotted using Sigma Plot for Windows Version 11.0 (Systat Software Inc., Germany). A duplication method was used before the actual analysis of the micro and macro-elements. The method employs three-axial geometry, thereby reducing background noise by radiation polarisation.

\section{Results}

\section{Phytochemical, total flavonoid and total phenolic} contents of NLE

The phytochemical screening of NLE revealed the presence of triterpenoids, saponins, flavonoids, tannins and phenolic compounds and the absence of alkaloids. The total flavonoid content of NLE was expressed as 
quercetin equivalent and extrapolated from the standard curve of quercetin (Fig. 1.1-A). Concentrations of 0.31 and $0.63 \mathrm{mg} / \mathrm{ml}$ of NLE contained 1.8 and $2.2 \mathrm{~g}$ of total flavonoid per $100 \mathrm{~g}$ of quercetin equivalent, respectively (Fig. 1.1-B). In the other hand, the total phenolic content of NLE, expressed as gallic acid equivalent, was extrapolated from the standard curve of gallic acid (Fig. 1.2-A). At concentrations of $2.5 ; 5.0$ and $10.0 \mathrm{mg} / \mathrm{ml}$ of NLE, the total phenolic contents determined were $10.5 ; 11.8$ and $10.6 \mathrm{~g} / 100 \mathrm{~g}$ of gallic acid equivalent, respectively (Fig. 1.2-B).

\section{Micro and macro-elements content of NLE}

A total of nine 9 macro-elements and 11 microelements were identified and quantified in NLE samples (Table 1). The macro-elements of mean values between 414 and $38,403 \mathrm{ppm}$ identified were magnesium $(\mathrm{Mg})$, aluminum $(\mathrm{Al})$, silicon $(\mathrm{Si})$, phosphorus $(\mathrm{P})$, sulphur $(\mathrm{S})$, potassium $(\mathrm{K})$, calcium $(\mathrm{Ca})$, manganese $(\mathrm{Mn})$, and iron $(\mathrm{Fe})$. While the micro-elements of mean values between 2 and $40 \mathrm{ppm}$ were copper $(\mathrm{Cu})$, zinc $(\mathrm{Zn})$, rubidium $(\mathrm{Rb})$, strontium $(\mathrm{Sr})$, yttrium $(\mathrm{Y})$, zirconium $(\mathrm{Zr})$, niobium $(\mathrm{Nb})$, silver $(\mathrm{Ag})$, cadmium $(\mathrm{Cd})$ and thorium $(\mathrm{Th})$. The content of the elements quantified in $N$. lotus leaves decreases in the order: $\mathrm{Si}>\mathrm{K}>\mathrm{Ca}>\mathrm{Mg}>\mathrm{Al}>\mathrm{Fe}>\mathrm{S}>$ $\mathrm{P}>\mathrm{Mn}>\mathrm{Ag}>\mathrm{Zn}>\mathrm{Rb}>\mathrm{Sr}>\mathrm{Cd}>\mathrm{Th}>\mathrm{Zr}>\mathrm{Cu}>\mathrm{Nb}>\mathrm{Y}$.

\section{Antioxidant activities of NLE}

The extract and BHT exhibited a concentrationdependent scavenging activity of DPPH (Fig. 2a). The concentration of NLE required to inhibit $50 \%$ of free radicals $\left(\mathrm{IC}_{50}\right)$ was $0.0976 \pm 0.25 \mathrm{mg} / \mathrm{ml}$ compared to $0.2188 \pm 0.02 \mathrm{mg} / \mathrm{ml}$ obtained for BHT (positive control). The difference in $\mathrm{IC}_{50}$ values between the NLE and BHT was statistically significant $(p<0.001)$ and NLE was found to be about two-fold more potent than BHT, in scavenging DPPH radicals. Also, both NLE and gallic acid caused a concentration-dependent inhibition of
Table 1 Content and limit of detection (ppm) of micro and macro-elements in Nymphaea lotus leaves

\begin{tabular}{lll}
\hline Elements & Mean $\pm \mathbf{3 \sigma}(\mathbf{p p m})$ & Limit of detection LOD $(\mathbf{p p m})$ \\
\hline $\mathrm{Mg}$ & $11,433 \pm 0.43$ & 1100 \\
$\mathrm{Al}$ & $7733 \pm 0.01$ & 95 \\
$\mathrm{Si}$ & $38,403 \pm 0.036$ & 160 \\
$\mathrm{P}$ & $2959 \pm 97$ & 10 \\
$\mathrm{~S}$ & $3225 \pm 68$ & 13 \\
$\mathrm{~K}$ & $21,500 \pm 0.021$ & 16 \\
$\mathrm{Ca}$ & $13,800 \pm 0.009$ & 17 \\
$\mathrm{Mn}$ & $414 \pm 28$ & 5 \\
$\mathrm{Fe}$ & $5859 \pm 87$ & 12 \\
$\mathrm{Cu}$ & $6 \pm 3$ & 2 \\
$\mathrm{Zn}$ & $33 \pm 3$ & 1 \\
$\mathrm{Rb}$ & $28 \pm 1$ & 1 \\
$\mathrm{Sr}$ & $19 \pm 1$ & 1 \\
$\mathrm{Y}$ & $2 \pm 1$ & 1 \\
$\mathrm{Zr}$ & $9 \pm 2$ & 1 \\
$\mathrm{Nb}$ & $3 \pm 2$ & 1 \\
$\mathrm{Ag}$ & $40 \pm 8$ & 2 \\
$\mathrm{Cd}$ & $16 \pm 9$ & 2 \\
$\mathrm{~Pb}$ & - & 2 \\
$\mathrm{Th}$ & $15 \pm 5$ & \\
\hline $\mathrm{Maco} a \mathrm{~m}$ & & 2
\end{tabular}

Macro and micro-elements content were measured on pellets of $\mathrm{N}$. lotus leave samples (32 mm diameter $\times 3 \mathrm{~mm}$ thickness) using energy dispersive $\mathrm{x}$-ray fluorescence (ED-XRF) spectroscopy (SPECTRO X-Lab 2000 spectrometer). Measurements were done in triplicate and data presented are expressed in $\mathrm{ppm}$ and are mean value $\pm 3 \sigma$. The limit of detection for light elements ( $\mathrm{Si}, \mathrm{Al}$, $\mathrm{Mg}$, and $\mathrm{Na}$ ) was in the range of $25-50 \mathrm{ppm}$ and $1-5 \mathrm{ppm}$ for heavy metals

lipid peroxidation (Fig. 2b). The $\mathrm{IC}_{50}$ values determined for NLE and gallic acid were $0.2367 \pm 0.006$ and $1.418 \pm 0.01 \mathrm{mg} / \mathrm{ml}$, respectively. The difference in $\mathrm{IC}_{50}$ values between the NLE and gallic acid was statistically significant $(p<0.001)$ and NLE was about six-fold more potent in inhibiting lipid peroxidation
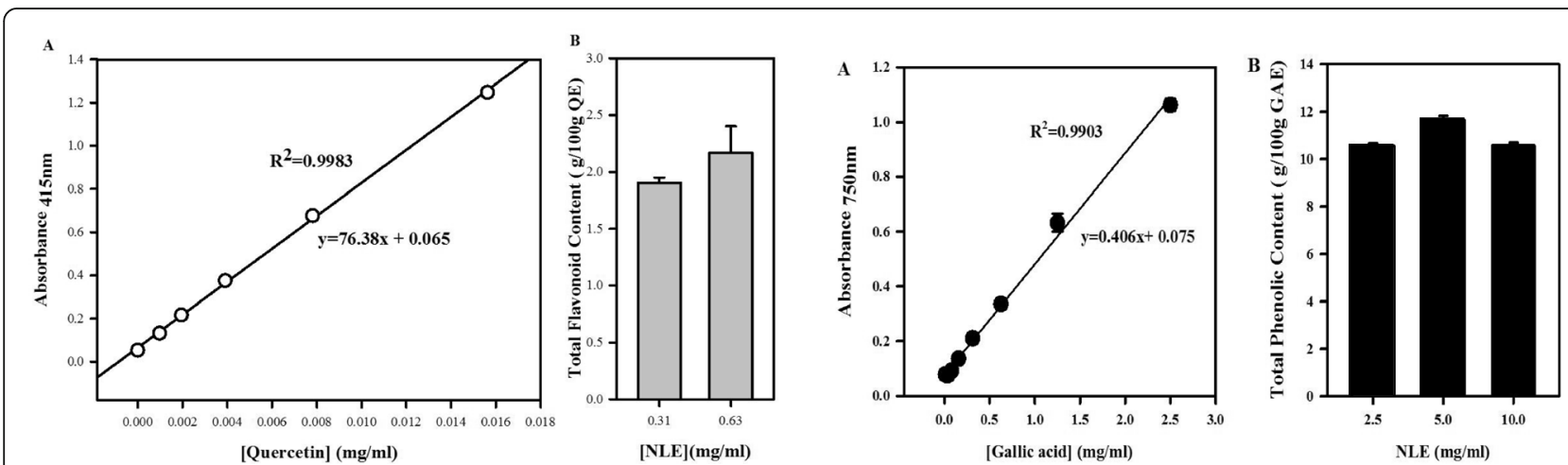

Fig. 1 Total flavonoids and total phenolic contents of the hydro-ethanolic extract of Nymphaea lotus (NLE) leaves. Panel 1.1: Total flavonoid content of NLE $(2.5 \mathrm{mg} / \mathrm{ml}-10 \mathrm{mg} / \mathrm{ml})$ expressed as quercetin equivalent (QE). Panel 1.2: Total phenolic content of various concentrations of NLE (2.5 mg/ml- 10 $\mathrm{mg} / \mathrm{ml}$ ) expressed as gallic acid equivalent (GAE). Each point represents the mean value \pm standard error on the mean $(\mathrm{SEM}),(n=3)$ 


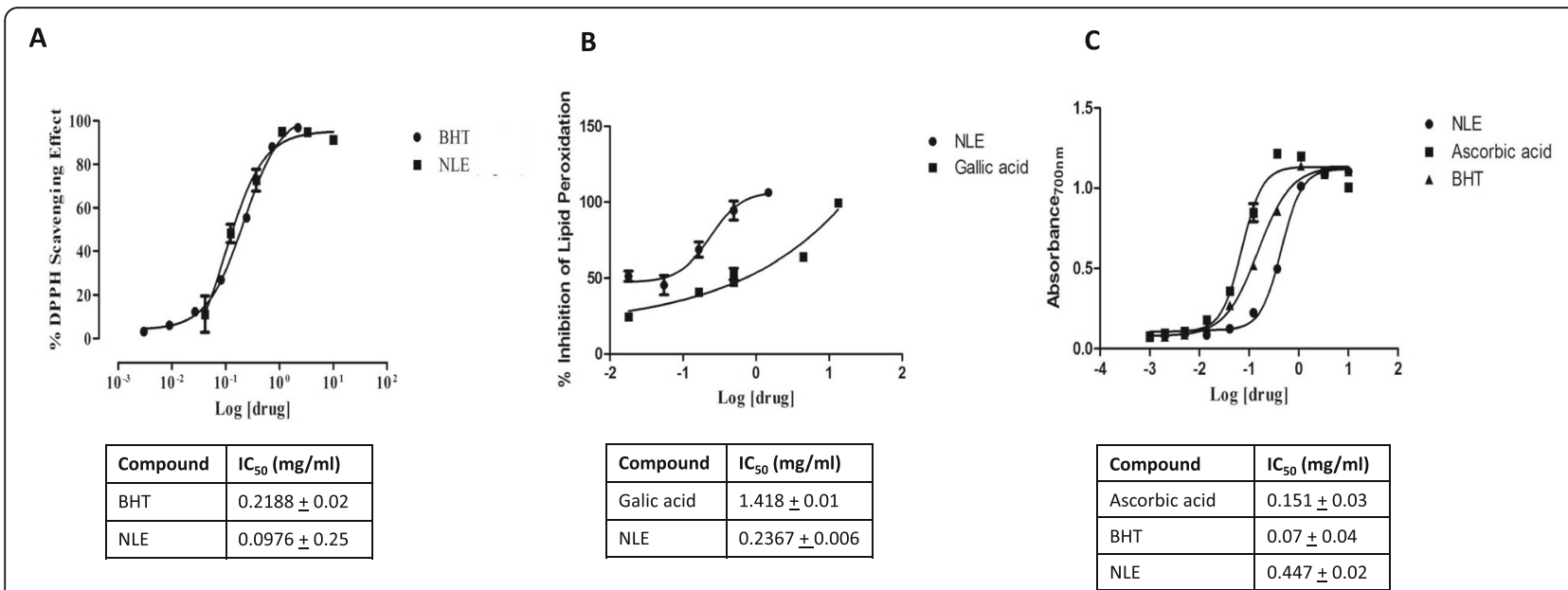

Fig. 2 Antioxidant activities of the hydro-ethanolic extract of Nymphaea lotus (NLE). a: 1,1-diphenyl-2-picryl hydrazyl radical (DPPH) radical scavenging activity, with each point representing mean value \pm standard error on the mean $(S E M)$, $(n=3)$. b: Inhibition of lipid peroxidation by NLE and gallic acid, with each point representing mean \pm SEM $(n=3)$. c: Reducing power of NLE, Ascorbic acid and butylated hydroxytoluene $(\mathrm{BHT})$, with each point representing mean $\pm \mathrm{SEM}(n=3)$

than gallic acid. The extract, ascorbic acid and BHT showed a concentration-dependent reducing power (Fig. 2c). $\mathrm{IC}_{50}$ determined were $0.447 \pm 0.02 ; 0.151 \pm$ 0.03 and $0.07 \pm 0.04 \mathrm{mg} / \mathrm{ml}$, for NLE, ascorbic acid and $\mathrm{BHT}$, respectively. There were significant differences $(p<0.001)$ between the $\mathrm{IC}_{50}$ values of NLE, ascorbic acid and BHT. However, NLE was about 3 and 6-fold less potent than ascorbic acid and BHT, respectively, in reducing $\mathrm{Fe}^{3+}$ to $\mathrm{Fe}^{2+}$.

\section{Anti-inflammatory activities of NLE Rat paw oedema reduction}

Sub-plantar injection of carrageenan in the paw induced oedema (in all rats) which size increased with time till 4 $\mathrm{h}$ and then spontaneously decreased till $24 \mathrm{~h}$ after injection (Fig. 3). However, rats pre-treated with NLE or standard drugs (diclofenac and hydrocortisone) exhibited significantly reduced paw oedema sizes at all points measured in time when compared to the negative controls. These effects of NLE and standard drugs on the oedema size were time- and dose-dependent and were statistically significant among groups $(p<0.05$ and $p<$ 0.0001 respectively).

\section{Skin prick test}

Intradermal injection of histamine induced the formation of a wheal on the skin of all rats (Fig. 4). An hour after histamine injection, only rats pre-treated with hydrocortisone presented a significantly reduced wheal diameter, when compared to the negative control group $(p<0.05)$. However, $2 \mathrm{~h}$ after histamine injection, rats pre-treated with NLE or the standard drug (hydrocortisone) exhibited a significantly reduced wheal diameter, as compared to the negative control. These effects of
NLE and the standard drug on the wheal diameter were time- and dose-dependent and were statistically significant at NLE 250 and $500 \mathrm{mg} / \mathrm{kg} \quad(\mathrm{p}<0.05$ and $\mathrm{p}<$ 0.0001).

\section{Erythrocyte sedimentation rate (ESR)}

Control rats sensitised by ovalbumin showed a significantly increased ESR $(p<0.01)$ when compared to the non-sensitized rats. Ovalbumin-sensitized rats treated with increasing doses of NLE exhibited a dosedependent decrease of the ESR. However, this NLEinduced decrease of ESR was significant at 250 and 500 $\mathrm{mg} / \mathrm{kg}(\mathrm{p}<0.05$ and $\mathrm{p}<0.01$ respectively). Also, ESR was significantly decreased $(\mathrm{p}<0.01)$ in rats treated with hydrocortisone when compared the control sensitised rats (see Fig. 5).

\section{Effect of NLE on MCF-7, Jurkat and Chang liver cell lines proliferation}

The effect of NLE on MCF-7, Jurkat and Chang liver cell lines proliferation is presented in Fig. 6. The extract and curcumin (positive control) exhibited concentrationdependent inhibition of MCF-7 with $\mathrm{IC}_{50}$ values of 5.180 and $155 \mu \mathrm{g} / \mathrm{ml}$ for curcumin and NLE, respectively. The difference between the $\mathrm{IC}_{50}$ values of NLE and curcumin were statistically significant $(p<0.001)$. Both NLE and curcumin inhibited the growth of Jurkat cells in a concentration-dependent fashion with $\mathrm{IC}_{50}$ values of 2.056 and $87.29 \mu \mathrm{g} / \mathrm{ml}$ for curcumin and NLE respectively and the difference was found to be statistically significant $(p<0.001)$. The extract and curcumin exhibited a concentration-dependent inhibition on Chang liver cell growth with $\mathrm{IC}_{50}$ values of 204.2 and $2.568 \mu \mathrm{g} / \mathrm{ml}$ for NLE and curcumin 
A

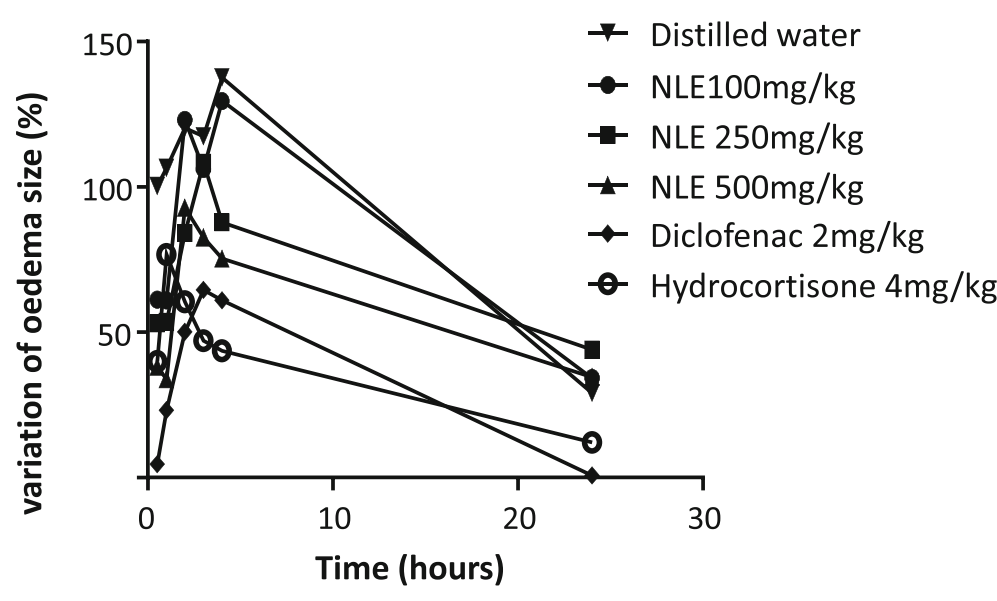

B

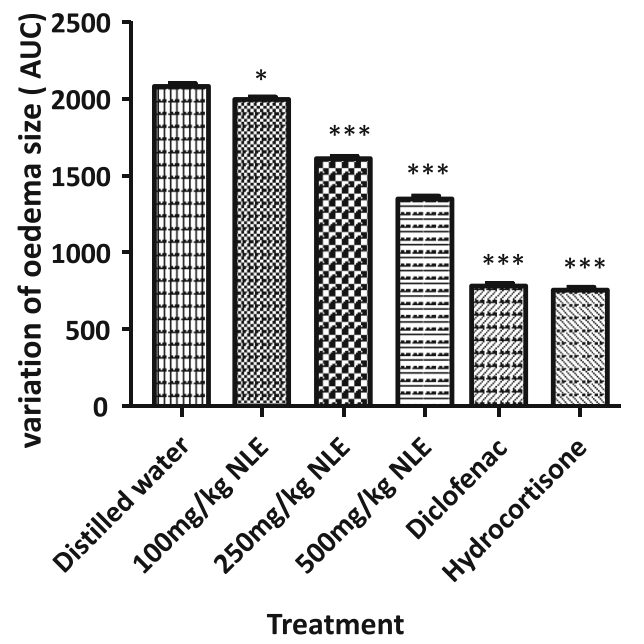

Fig. 3 Anti-inflammatory activities of the hydro-ethanolic extract of Nymphaea lotus leaves (NLE, 100, 250 and 500 mg/kg, p.o.), diclofenac (2 mg/ $\mathrm{kg}$ ) and hydrocortisone $(4 \mathrm{mg} / \mathrm{kg})$ on the paw oedema size in normal SD rats. Chart a shows the time course effects over a 24-h period; chart $\mathbf{b}$ shows the total percentage paw oedema's area under the curve (AUC) over the 24-h period. Data are mean value \pm standard error on the mean (SEM), $(n=5) .{ }^{*} p<0.05,{ }^{* *} p<0.001$ when compared to the negative control group, using one-way ANOVA followed by a Dunnett's Multiple Comparison Test

respectively and this difference was statistically significant $(\mathrm{p}<0.001)$.

\section{Discussion}

There is a growing body of evidence that suggests that oxidative stress and inflammation are two primary mechanisms leading to the initiation and development of cancers. This study sought to contribute to the management of cancer by investigating the antioxidant, antiinflammatory and cytotoxic activities of $N$. lotus (a medicinal plant traditionally used to manage cancer patients) in relation to its phytochemical and elemental constituents.
The phytochemical screening of the hydro-ethanol extract of N. lotus leaves (NLE) revealed the presence of triterpenoids, saponins, flavonoids, tannins and phenolic compounds and the absence of alkaloids. Also, the determination of the total phenol and total flavonoids contents of NLE extract revealed appreciable amounts of these two secondary metabolites. The presence of saponin, triterpenoids and considerable amounts of flavonoids and phenolic compounds in our extract could explain the antioxidant, anti-inflammatory and cytotoxic activities of NLE, as similarly reported by previous studies on aqueous and acetone extracts of $N$. lotus [48-50]. Likewise, these findings are consistent with a study
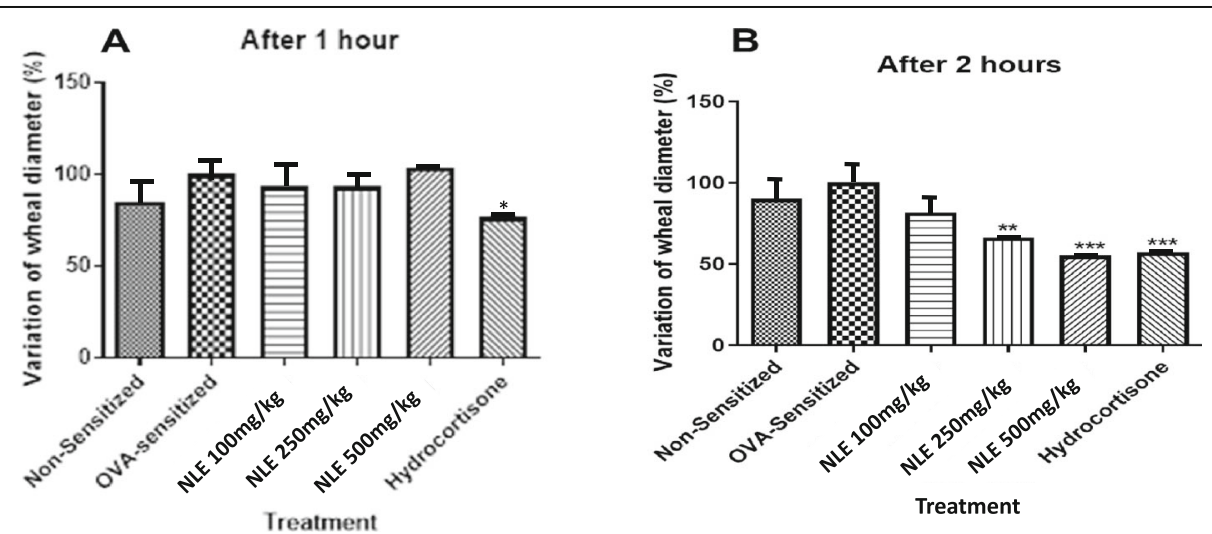

Fig. 4 Anti-inflammatory activities of the hydro-ethanolic extract of Nymphaea lotus leaves (NLE, 100, 250 and 500 mg/kg, p.o.) and hydrocortisone $(4 \mathrm{mg} / \mathrm{kg}$ ) on wheal diameter in ovalbumin (OVA)-sensitized SD rats, 1 and $2 \mathrm{~h}$ after intradermal injection of histamine. Data are mean value \pm standard error on the mean $(\mathrm{SEM}),(n=5) .{ }^{* *} p<0.01,{ }^{* * *} p<0.001$ when compared to the negative control group, using one-way ANOVA followed by a Dunnett's Multiple Comparison Test 


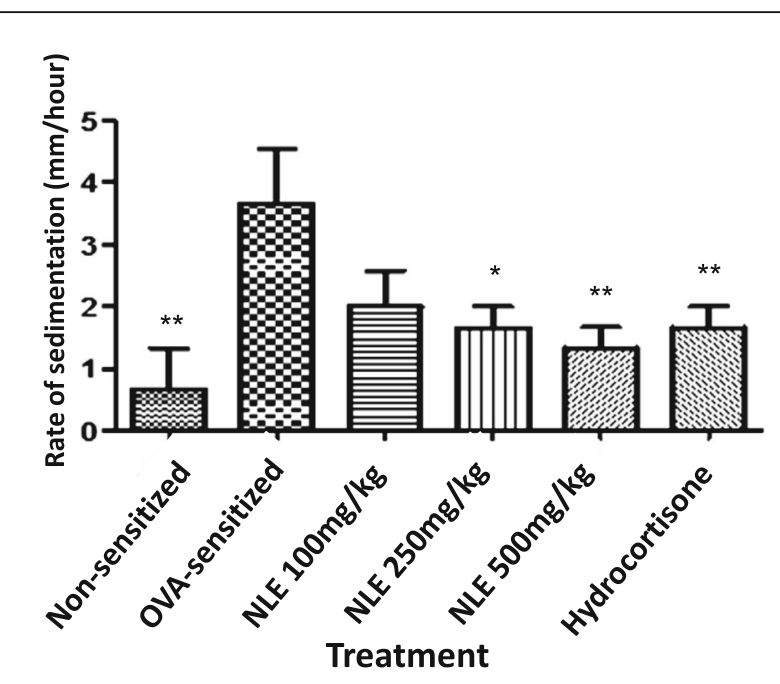

Fig. 5 Anti-inflammatory activities of the hydro-ethanolic extract of Nymphaea lotus leaves (NLE, 100, 250 and $500 \mathrm{mg} / \mathrm{kg}$, p.o.) and hydrocortisone $(4 \mathrm{mg} / \mathrm{kg})$ on the rate of sedimentation of erythrocyte (ESR) from blood samples of ovalbumin (OVA)-sensitized $\mathrm{SD}$ rats. Data are mean value \pm standard error on the mean (SEM), $(n=5) .{ }^{*} p<0.05,{ }^{* *} p<0.01$ when compared to the negative control group, using one-way ANOVA followed by a Dunnett's Multiple Comparison Test showing the presence of vitamins $\mathrm{A}, \mathrm{C}$ and $\mathrm{E}$ in $N$. lotus leaves [51]. Previous reports showed the presence of alkaloids in the chloroform, ethyl acetate, n-butanol, acetone and aqueous extracts of $N$. lotus leaves, in addition to the presence of phenolic compounds (flavonoids, coumarins and tannins), and sterols $[50,52]$. The absence of alkaloids in our extract (NLE) could be due to solvent system used for the extraction or the geographical location of plants collected. Our choice for the hydroethanolic system was because we wanted to mimic, as much as possible, the traditional preparation of $N$. lotus.

The elemental content of NLE sample was measured by energy dispersive $\mathrm{x}$-ray fluorescence spectroscopy (ED-XRF). It is a fast, reliable and powerful analytical tool for the determination of the elemental composition of diverse materials (particularly for high energy elements) and does not produce waste and requires no chemical reagents [53]. A total of nine 9 macro and 11 micro-elements were identified and quantified in the NLE sample (Table 1). The content of various elements analyzed in $\mathrm{N}$. lotus leaves decreases in the order: $\mathrm{Si}>$ $\mathrm{K}>\mathrm{Ca}>\mathrm{Mg}>\mathrm{Al}>\mathrm{Fe}>\mathrm{S}>\mathrm{P}>\mathrm{Mn}>\mathrm{Ag}>\mathrm{Zn}>\mathrm{Rb}>\mathrm{Sr}>$ $\mathrm{Cd}>\mathrm{Th}>\mathrm{Zr}>\mathrm{Cu}>\mathrm{Nb}>\mathrm{Y}$. Macro-elements such as magnesium (Mg), phosphorus (P), sulphur (S) and

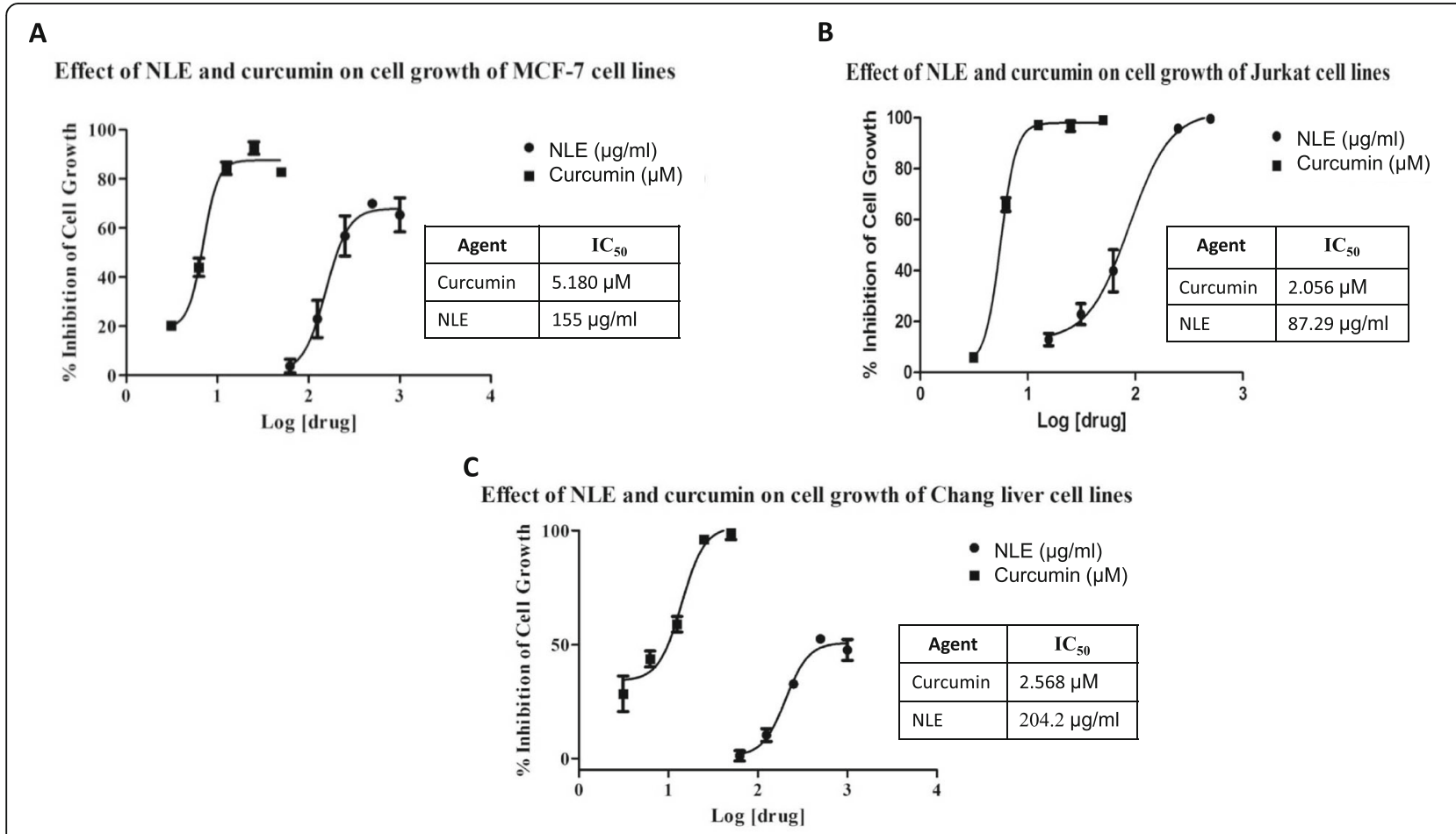

Fig. 6 Cytotoxic activities of the hydro-ethanolic extract of Nymphaea lotus leaves (NLE) and curcumin on cell growth of breast cancer (MCF-7) cell line (a), leukaemia (Jurkat) cell line $(\mathbf{b})$ and Chang liver cells (c). Each point represents the mean value \pm standard error on the mean $(\mathrm{SEM}),(\mathrm{n}=3)$ 
micro-elements such as manganese $(\mathrm{Mn})$, copper $(\mathrm{Cu})$ and zinc $(\mathrm{Zn})$ present in NLE sample have been reported to be relevant elements as anti-cancer adjuvants $[54,55]$. These elements are known to play important roles in cellular metabolism, as co-factors in numerous enzymatic activities, or as important components of structural proteins such as hormones involved in cancer therapy [56]. Copper and zinc have been reported to be involved in the elimination of free radicals through cascading enzyme systems [57]. Thus, the presence of these elements in NLE could support the traditional use of $N$. lotus as an anticancer medicinal plant and also explain the antioxidant, anti-inflammatory and cytotoxic activities of NLE reported in this study. Moreover, cadmium (Cd), a toxic heavy metal, was detected in the NLE sample. Lead was below the detectable limit. These findings are almost similar to results reported [51] using a flame photometer and an atomic absorption spectrophotometer (AAS). This finding proved that results obtained using ED-XRF or AAS methods are not significantly different [58]. However, it is important to note that acute or chronic exposure of an organism to these toxic elements (which are usually contaminants from the environment) present in medicinal plants could result in the development of unwanted toxicopathies [59]. Therefore, the presence of these toxic elements (but not $N$. lotus itself) could explain the toxic effects of the hydro-ethanolic and hydro-methanolic extracts of $N$. lotus reported in the literature. These toxic effects were characterised by an induction of a chromosomal aberration in rat lymphocytes, an increase of aberrant sperm cells and somatic genotoxicity $[49,60]$.

The antioxidant activity of NLE extract was determined using DPPH radical scavenging assay, lipid peroxidation inhibition assay and reducing power assay. The DPPH radical scavenging assay revealed that NLE was about two times more potent than BHT in scavenging DPPH. This result shows that NLE has a strong antioxidant potential, and that could be attributed to its phenolic, flavonoid and elemental contents. A correlation between phenolic compounds, micro-element content and antioxidant activity has been reported in the literature [61-63]. In the current study, NLE was also found to be about six-fold more potent in inhibiting lipid peroxidation than gallic acid. The extract's ability to inhibit lipid peroxidation could be attributed to the presence of lipid-soluble antioxidant compounds, hence, could donate protons to stabilize lipid radicals or exquisitely scavenges lipid peroxyl radicals, thereby, terminating subsequent chain propagation reactions [64]. In a reducing power assay, the oxidative form of iron $\left(\mathrm{Fe}^{3+}\right)$ in ferric chloride is converted to ferrous $\left(\mathrm{Fe}^{2+}\right)$ by antioxidant compounds. The extract was not as potent as ascorbic acid or BHT in reducing $\mathrm{Fe}^{3+}$ to $\mathrm{Fe}^{2+}$. In a similar study, the hydro-alcohol and chloroform extracts of $\mathrm{Nyc}$ tantes arbour were found to be as potent as ascorbic acid in reducing power property [65].

The anti-inflammatory activity of NLE extract was measured using carrageenan-induced rat paw oedema assay, skin prick test and erythrocyte sedimentation rate assay. Carrageenan-induced rat paw oedema model is an appropriate test commonly used in screening of antiinflammatory agents. The biphasic acute inflammation induced by carrageenan is characterized by the release of pro-inflammatory mediators such as kinins, histamine and serotonin, in the first phase [66], followed by the release of prostaglandins-like substances, the main mediators causing the acute inflammation [67]. This later phase is responsive to clinically useful anti-inflammatory agents [68]. The extract significantly decreased paw oedema sizes in a dose-dependent manner, thus, might be containing some anti-inflammatory compounds causing the inhibition of prostaglandin-induced inflammatory pathway. Subcutaneous injection of histamine (or other allergens) causes mast cells to degranulate and release histamine and other mediators, following the cross-linkage of specific IgE bound to their surface receptors. This leads to a triple response characterized by a capillary dilatation (causing a red spot), an arteriolar dilatation mediated by axon reflex leading to a flare (causing the redness in the surrounding area) and an exudation of fluid from venules and capillaries (causing the formation of a wheal), which wheal can be quantitated by measuring its diameter [44]. Thus, the skin prick test was used to measure the anti-inflammatory effect of NLE on the immunoglobulin E (IgE) response to ovalbumin (OVA) and on the vasodilatory activity of a preformed mediator, histamine, in sensitized rats. The extract significantly decreased wheal diameters in a dose-dependent manner, thus, might be containing antiinflammatory compounds that could also block mast cells degranulation and the release histamine (or other mediators). Erythrocyte sedimentation rate assay measures the distance that erythrocytes have sedimented (under the influence of gravity) after $1 \mathrm{~h}$ in a vertical column of anticoagulated blood. The main factor influencing and directly correlating with the sedimentation rate is the amount of fibrinogen in the blood. The extract significantly decreased the ESR in a dose-dependent manner, thus, might be containing anti-inflammatory compounds that could block the synthesis of fibrinogen. Altogether, these results showed a consistent antiinflammatory activity of NLE extract. These findings are consistent with the traditional use of $N$. lotus as antiinflammatory medicine [69] to treat arthritis and rheumatic pains [70].

Invasive ductal carcinoma is the commonest histological type of breast cancer in Africa and acute T-cell 
leukemia exhibits a very aggressive course of progression with poor prognosis associated with shorter overall survival. Therefore, there is a need to discover new effective agents against these two types of cancer. MCF-7 is a human adenocarcinoma breast cancer cell line with estrogen, progesterone and glucocorticoid receptors, while Jurkat cell line was derived from human acute T-cell leukaemia. These two cell lines are excellent models for screening anticancer (cytotoxic) agents. The cytotoxic activity of NLE extract was determined using an MTT assay. Both NLE and curcumin (positive control) exhibited cytotoxic activities on MCF-7 and Jurkat cell lines, however, NLE was not as potent as curcumin. This difference could be explained by the fact that curcumin is a pure isolated compound and NLE is a crude extract containing several active compounds which could have antagonistic effects on each other. The cytotoxic activity of NLE revealed some cell-specificity for Jurkat cell line, as shown by the $\mathrm{IC}_{50}$ values of NLE for Jurkat and MCF-7. Interestingly, NLE showed less cytotoxic activity on Chang liver cells (normal cell line) when compared to the cancer cell lines (Jurkat and MCF-7). In the opposite, curcumin rather showed a potent cytotoxic activity on Chang liver cell line. These results corroborate similar antiproliferative studies on the cytotoxic activities of Nymphea lotus (whole plant), Nymphea alba and Nymphaea mexicana $[27,71]$ and could be attributed to the phytochemical and elemental contents of $N$. lotus leaves and therefore, could justify its traditional use as cancer treatment. Further bioactivity-guided fractionation studies would be necessary to isolate the active compounds responsible for the aforementioned activities.

\section{Conclusion}

Our results showed that the hydro-ethanolic extract of $N$. lotus leaves possesses high antioxidant potential, antiinflammatory property and cytotoxic activity on MCF-7 and Jurkat cancer cell lines. These properties could be attributed to the presence of appreciable amounts of total phenol and flavonoids, as well as to the presence of macro/micro-elements such as magnesium, phosphorus, sulphur, manganese, copper and zinc. However, the presence of heavy metals such as cadmium detected in $N$. lotus leaves could explain the toxic effects of the hydro-ethanolic extract of $N$. lotus previously reported in the literature. Altogether, our findings could explain the use of $N$. lotus leaves in the traditional management of cancer patients and justify the use of this plant as a source for the discovery of new anticancer agents with cytotoxic, antioxidant and anti-inflammatory properties.

\footnotetext{
Abbreviations

ANOVA: Analysis of variance; AUC: Area under the curve; BHT: Butylated hydroxytoluene; DPPH: 2, 2 diphenyl-1-picrylhydrazyl; ED-XRF: Energy dispersive $\mathrm{X}$-ray; ESR: Erythrocyte sedimentation rate; $\mathrm{IC}_{50}$ : Inhibitory
}

concentration 50; MTT: 3-(4,5-dimethylthiazol-2-YI)-2,5-diphenyltetrazolium bromide; NCDs: Non-communicable diseases; NLE: Nymphaea lotus ethanolic extract; OS: Oxidative stress; SEM: Standard error on the mean; SD: SpragueDawley (rats); WHO: World health organisation

\begin{abstract}
Acknowledgements
The authors are grateful to the Non-Governmental Organisation for the Promotion of Scientific Research in African Traditional Medicine (NGO "PRORESMAT") and to the late Mr. Kafongo Kignelman Ouattara (Abidjan, Cote d'Ivoire) for introducing Dr. Benoit Banga N'guessan to the herbalist. Also, we wish to thank the herbalist Mr. Digbeu Luc Gouda (Abidjan, Cote d'Ivoire) for accepting to collaborate with us and for helping in the collection of the plant material. We are also grateful to all laboratory technicians at the School of Pharmacy and Noguchi Memorial Institute for Medical Research (NMIMR), University of Ghana, for their help and technical support.
\end{abstract}

\section{Authors' contributions}

BBN conceived the study. BBN, PA, SFM and RAO designed the methodology. ADA, NKA performed the experimental work under the supervision of BBN and RAO. BBN, ADA, NKA and SFM conducted the collection of data. BBN, ADA, NKA, SFM, SKA, KEK, JAS, KFMO, IJAG and RAO performed the data analysis. BBN, ADA, NKA, SFM, SKA, KEK, JAS, KFMO, IJAG and RAO were involved in the writing of the manuscript. All authors read and approved the final manuscript.

\section{Funding}

The authors have no support or funding to report.

\section{Availability of data and materials}

The data used to support the findings of this study are available from the corresponding author upon request.

\section{Ethics approval and consent to participate}

This research was reviewed and approved by the Ethical and Protocol Review Committee of the College of Health Sciences, University of Ghana (Protocol Identification Number: CHS-Et/M.6-P1.5/2017-2018) and was conducted in accordance with the internationally accepted principles for laboratory animal use and care as found in the US guidelines (NIH publication \#85-23, revised in 1985).

\section{Consent for publication}

Not applicable.

\section{Competing interests}

Dr. Patrick Amoateng declares that he is a member of the editorial board (Associate Editor) of this journal. All other authors declare that they have no competing interests.

\section{Author details}

${ }^{1}$ Department of Pharmacology and Toxicology, School of Pharmacy, College of Health Sciences, University of Ghana, P.O. Box LG 43, Legon, Accra, Ghana. ${ }^{2}$ Department of Pharmaceutical Chemistry, School of Pharmacy, College of Health Sciences, University of Ghana, P.O. Box LG 43, Legon, Accra, Ghana. ${ }^{3}$ Department of Pharmacognosy and Herbal Medicine, School of Pharmacy, College of Health Sciences, University of Ghana, P.O. Box LG 43, Legon, Accra, Ghana. ${ }^{4}$ Department of Clinical Pathology, Noguchi Memorial Institute for Medical Research (NMIMR), College of Health Sciences, University of Ghana, Accra, Ghana.

Received: 13 March 2020 Accepted: 17 December 2020

Published online: 07 January 2021

\section{References}

1. Holmes MD, Dalal S, Volmink J, Adebamowo CA, Njelekela M, Fawzi WW, Willett WC, Adami H-O. Non-communicable diseases in sub-Saharan Africa: the case for cohort studies. Plos Med. 2010;7(5):e1000244.

2. Mensah GA, Mayosi BM. The 2011 United Nations high-level meeting on non-communicable diseases: the Africa agenda calls for a 5-by-5 approach. S Afr Med J. 2013;103(2):77-9.

3. Mudie K, Jin MM, Tan, Kendall L, Addo J, Dos-Santos-Silva I, Quint J Smeeth L, Cook S, Nitsch D et al. Non-communicable diseases in sub- 
Saharan Africa: a scoping review of large cohort studies. J Glob Health. 2019:9(2):020409.

4. Camps J, García-Heredia A. Introduction: oxidation and inflammation, a molecular link between non-communicable diseases. In: Oxidative Stress and Inflammation in Non-communicable Diseases-Molecular Mechanisms and Perspectives in Therapeutics. edn. Switzerland: Springer International Publishing; 2014. p. 1-4.

5. Hussain SP, Hofseth $\sqcup$, Harris CC. Radical causes of cancer. Nat Rev Cancer. 2003;3(4):276-85.

6. New Global Cancer Data. GLOBOCAN 2018 [https://www.uicc.org/news/ new-global-cancer-data-globocan-2018\#]. Accessed 7 Nov 2019.

7. Bray F, Ferlay J, Soerjomataram I, Siegel RL, Torre LA, Jemal A. Global cancer statistics 2018: GLOBOCAN estimates of incidence and mortality worldwide for 36 cancers in 185 countries. CA Cancer J Clin. 2018;68(6):394-424.

8. Ferlay J, Colombet M, Soerjomataram I, Mathers C, Parkin D, Piñeros M, Znaor A, Bray F. Estimating the global cancer incidence and mortality in 2018: GLOBOCAN sources and methods. Int J Cancer. 2019;144(8):1941-53.

9. [https://www.who.int/news-room/fact-sheets/detail/cancer]. Accessed 7 Nov 2019.

10. Tsukasaki K, Hermine O, Bazarbachi A, Ratner L, Ramos JC, Harrington Jr W, O'Mahony D, Janik JE, Bittencourt AL, Taylor GP. Definition, prognostic factors, treatment, and response criteria of adult T-cell leukemia-lymphoma: a proposal from an international consensus meeting. J Clin Oncol. 2009; 27(3):453.

11. Edmund DM, Naaeder SB, Tettey Y, Gyasi RK. Breast cancer in Ghanaian women: what has changed? Am J Clin Pathol. 2013;140(1):97-102.

12. Anim J. Breast cancer in sub-Saharan African women. J Afr J Med Med Sci. 1993:22(1):5-10

13. Fregene A, Newman LA. Breast cancer in sub-Saharan Africa: how does it relate to breast cancer in African-American women? Cancer. 2005;103(8): 1540-50.

14. Marçais A, Suarez F, Sibon D, Frenzel L, Hermine O, Bazarbachi A. Therapeutic options for adult T-cell leukemia/lymphoma. Curr Oncol Rep. 2013;15(5):457-64.

15. Vose JAJ, Weisenburger D. International peripheral T-cell and natural killer/Tcell lymphoma study: pathology findings and clinical outcomes. J Clin Oncol. 2008;26:4124-30.

16. Zugazagoitia J, Guedes C, Ponce S, Ferrer I, Molina-Pinelo S, Paz-Ares L. Current Challenges in Cancer Treatment. Clin Ther. 2016;38(7):1551-66.

17. Albulescu M. Phytochemicals in Antitumor Herbs and Herbal Formulas. In: Phytochemicals-Isolation, Characterisation and Role in Human Health. edn. London: IntechOpen; 2015.

18. Desai AG, Qazi GN, Ganju RK, El-Tamer M, Singh J, Saxena AK, Bedi YS, Taneja SC, Bhat HK. Medicinal plants and cancer chemoprevention. Curr Drug Metab. 2008;9(7):581-91.

19. Ulrich-Merzenich $G$, Zeitler $H$, Jobst $D$, Panek $D$, Vetter $H$, Wagner $H$. Application of the "-Omic-" technologies in phytomedicine. Phytomedicine. 2007;14(1):70-82.

20. Oyebode O, Kandala NB, Chilton PJ, Lilford RJ. Use of traditional medicine in middle-income countries: a WHO-SAGE study. Health Policy Plan. 2016;31(8): 984-91.

21. World Health Organization W, Traditional Medicine Growing Needs and Potential. In: WHO Policy Perspectives on Medicines. vol. No. 002 May. Geneva: World Health Organization; 2002. p. 6.

22. World Health Organization W. Traditional Medicine Growing Needs and Potential. In: WHO Policy Perspectives on Medicines. vol. No. 002 May. World Health Organization; 2002. p. 6. Accessed 10 Nov 2019.

23. Bent S. Herbal medicine in the United States: review of efficacy, safety, and regulation. J Gen Intern Med. 2008;23(6):854-9.

24. Everett TH. The New York botanical garden illustrated encyclopedia of horticulture, vol. 10. Taylor \& Francis New York; 1982.

25. Slocum PD. Waterlilies and lotuses. Species, cultivars, and new hybrids. Portland: Timber Press; 2005.

26. Bouquet A. Féticheurs et médecine traditionnelle du Congo (Brazzaville): Mem. Paris: O.R.S.T.O.M; 1969.

27. Ashidi J, Houghton P, Hylands P, Efferth T. Ethnobotanical survey and cytotoxicity testing of plants of South-Western Nigeria used to treat cancer, with isolation of cytotoxic constituents from Cajanus cajan Millsp. Leaves. J Ethnopharmacol. 2010;128(2):501-12.

28. Doka I, Yagi S. Ethnobotanical survey of medicinal plants in West Kordofan (Western Sudan). Ethnobotanical leaflets. 2009;2009(11):8.
29. Kerharo J, Adam JG. African medicinal plants. Plants with medicinal, toxic and magical properties of Niominka and Soce of the saloum Islands (Senegal). Acta Trop. 1964(Suppl. 8):279-334.

30. Kameni P, Dzeufiet D, Bilanda D, Mengue N, Mballa M. Protective effects of Nymphaea lotus Linn.(Nymphaeaceae) aqueous extract against chronic unpredictable mild stress induced testicular lipid peroxidation. Asian J Biomed Pharm Sci. 2016;6(54):1-6.

31. Saleem A, Ahotupa M, Pihlaja K. Total phenolics concentration and antioxidant potential of extracts of medicinal plants of Pakistan. Z Naturforsch. 2001;56(11-12):973-8.

32. Elegami AA, Bates C, Gray Al, Mackay SP, Skellern GG, Waigh RD. Two very unusual macrocyclic flavonoids from the water lily Nymphaea lotus. Phytochemistry. 2003;63(6):727-31.

33. Gareth T. Medicinal Chemistry, 2nd edition edn. New Jersey: Wiley; 2007.

34. Eyal R. Micro-elements in agriculture: practical hydroponics and greenhouses; 2007.

35. World Health Organization W. Quality control methods for medicinal plant materials. Geneva: World Health Organization; 1998.

36. Carvalho ML, Ferreira JG, Amorim P, Marques MI, Ramos MT. Study of heavy metals and other elements in macrophyte algae using energy-dispersive $x$ ray fluorescence. Environ Toxicol Chem. 1997;16(4):807-12.

37. N'Guessan BB, Dosso K, Gnangoran BN, Amoateng P, Asiedu-Gyekye IJ, Yapo AP. Antibacterial and antispasmodic activities of a dichloromethane fraction of an ethanol extract of stem bark of Piliostigma reticulatum. J Pharm Bioallied Sci. 2015;7(2):128-35.

38. Languon S, Tuffour I, Quayson EE, Appiah-Opong R, Quaye O. In Vitro Evaluation of Cytotoxic Activities of Marketed Herbal Products in Ghana. J Evidence-Based Integrative Med. 2018;23:2515690X18790723.

39. N'guessan BB, Amponsah SK, Dugbartey GJ, Awuah KD, Dotse E, Aning A, Kukuia KKE, Asiedu-Gyekye IJ, Appiah-Opong R. In vitro antioxidant potential and effect of a glutathione-enhancer dietary supplement on selected rat liver cytochrome P450 enzyme activity. Evid Based Complement Alternat Med. 2018;2018:7462839.

40. Frimpong-Manso S, Asiedu-Gyekye I, Naadu J, Magnus-Aryitey G, Nyarko A, Boamah D, Awan M. Micro and macro element composition of Kalanchoe integra leaves: an adjuvant treatment for hypertension in Ghana. Int J Hypertens. 2015;2015.

41. Jayaprakasha G, Patil BS. In vitro evaluation of the antioxidant activities in fruit extracts from citron and blood orange. Food Chem. 2007;101(1):410-8.

42. Ganie SA, Haq E, Masood A, Hamid A, Zargar MA. Antioxidant and protective effect of ethyl acetate extract of hexandrum rhizome on carbon tetrachloride induced rat liver injury. Evid Based Complement Alternat Med. 2011;2011:238020

43. Silva FRF, Dore CMPG, Marques $C T$, Nascimento MS, Benevides NMB, Rocha HAO, Chavante SF, Leite EL. Anticoagulant activity, paw edema and pleurisy induced carrageenan: Action of major types of commercial carrageenans. Carbohydrate Polymers. 2010;79(1):26-33.

44. Julius A-GI, Charles A, Samuel NE, Ansong AD, Mahmood S, Samuel A, Kwame BNB, Patrick A, Edwin N. Nutraceutical with anti-inflammatory activity for the Management of Airway Remodeling in bronchial asthma: Kalanchoe integra Var. Crenata (Andr.) Cuf leaf extract. Pharmacol Pharm. 2014;5:250-61.

45. Boroviczeny K-GV, Bottiger LE, Chattas A, Dawson JB, Fukutake K, Gunz FW, Lewis SM, Rewald E, Roubicek M, Ruhenstroth-Bauer G, Westergren A. Reference method for the erythrocyte sedimentation rate (ESR) test on human blood. J Clin Pathol. 1973;26(4):301-2.

46. Thomas RD, Westengard JC, Hay KL, Bull BS. Calibration and validation for erythrocyte sedimentation tests. Role of the international committee on standardization in hematology reference procedure. Arch Pathol Lab Med. 1993;117(7):719-23.

47. Appiah-opong R, Asante IK, Safo DO, Tuffour I, Ofori-attah E, Uto T, Nyarko AK. Cytotoxic effects of Albizia zygia (DC) J. F. MACBR, a Ghanaian medicinal plant, against human t-lymphoblast-like leukemia, prostate and breast cancer cell lines. Int J Pharm Pharm Sci. 2016;8(5):392-96.

48. Laszczyk MN. Pentacyclic triterpenes of the Lupane, oleanane and ursane group as tools in cancer therapy. Planta Med. 2009;75(15):1549-60.

49. Oyeyemi ITYO, Odusina PO, Ologun TM, Ogbaide OM. Genotoxicity and anti-genotoxicity study of aqueous and hydro-methanol extracts of Spondias mombin L., Nymphaea lotus L. and Luffa cylindrical L. using animal bioassays. Interdiscip Toxicol. 2015;8(4):184-92.

50. Afolayan AJ, Sharaibi OJ, Kazeem MI. Phytochemical analysis and in vitro antioxidant activity of Nymphaea lotus L. Int J Pharmacol. 2013;9(5):297-304. 
51. Wasagu R, Lawal M, Galadima L, Aliero AJBJop. sciences a. Nutritional composition, antinutritional factors and elemental analysis of Nymphaea lotus (water lily). Bajopas. 2015:8(1):1-5.

52. Roger KG, Christelle AN, Akhanovna M-BJ, Yves-Alain B. CCM d'extraits sélectifs de 10 plantes utilisées dans le traitement Traditionnel du Cancer du sein en Côte d'Ivoire. Eur J Sci Res. 2011;63(4):592-603.

53. Howard DL, de Jonge MD, Lau D, Hay D, Varcoe-Cocks M, Ryan CG, Kirkham R, Moorhead G, Paterson D, Thurrowgood D. High-definition X-ray fluorescence elemental mapping of paintings. Anal Chem. 2012;84(7):327886.

54. Mulhern S: Effect of dietary zinc on lymphocyte stimulation and tumor susceptibility in the mouse. In: Federation Proceedings: 1980: Federation Amer Soc Exp Biol 9650 Rockville Pike, Bethesda, MD 20814-3998; 1980: 1126-1126.

55. Deheinzelin D, Negri E, Tucci M, Salem M, Da Cruz V, Oliveira R, Nishimoto I, Hoelz C. Hypomagnesemia in critically ill cancer patients: a prospective study of predictive factors. Brazilian J Med Biol Res. 2000;33(12):1443-8.

56. Skalnaya M, Skalny AV. Essential trace elements in human health: a physician's view. Tomsk: Publishing House of Tomsk State University; 2018.

57. Chan S, Gerson B, Subramaniam S. The role of copper, molybdenum, selenium, and zinc in nutrition and health. Clin Lab Med. 1998;18(4):673-85.

58. Djingova R, Ivanova J, Kuleff I. Comparative evaluation of the possibilities of INAA, ED-XRF, ICP-AES and AAS in the analysis of plants. J Radioanal Nucl Chem. 1998;237(1-2):25-34.

59. Nasri H. Toxicity and safety of medicinal plants. J HerbMed Pharmacol. 2013; 2(2):21-2.

60. Sowemimo A, Fakoya F, Awopetu I, Omobuwajo O, Adesanya S. Toxicity and mutagenic activity of some selected Nigerian plants. J Ethnopharmacol. 2007;113(3):427-32.

61. Cos P, Ying L, Calomme M, Hu JP, Cimanga K, Van Poel B, Pieters L, Vlietinck AJ, Berghe DV. Structure- activity relationship and classification of flavonoids as inhibitors of xanthine oxidase and superoxide scavengers. J Nat Prod. 1998;61(1):71-6.

62. Heim KE, Tagliaferro AR, Bobilya DJ. Flavonoid antioxidants: chemistry, metabolism and structure-activity relationships. J Nutr Biochem. 2002;13(10): 572-84.

63. Croft KD. The chemistry and biological effects of flavonoids and phenolic acids. Ann N Y Acad Sci. 1998;854(1):435-42.

64. Wang X, Quinn PJ. Vitamin E and its function in membranes. Prog Lipid Res. 1999;38(4):309-36.

65. Kaur P, Kashyap P, Katoch N, Gupta S, Singh R. Pharmacological evaluation of hydroalcohol and chloroform extracts of Nyctanthes arbour-tristis $L$. for antioxidant, anti-inflammatory and analgesic activity. Int J Pharm Pharm Sci. 2014;6:460-5.

66. Bhukya B, Anreddy RNR, William CM, Gottumukkala KM. Analgesic and antiinflammatory activities of leaf extract of Kydia calycina Roxb. Bangladesh J Pharmacol. 2009;4(2):101-4.

67. Wills AJP. Peptides, Amins: Release of histamin, kinin and prostaglandins during carrageenin induced inflammation of the rats; 1969. p. 31-48.

68. Brooks PM, Day RO. Nonsteroidal antiinflammatory drugs - differences and similarities. N Engl J Med. 1991;324(24):1716-25.

69. Madhusudhanan N, Lakshmi T, Gowtham KS, Ramakrishanan Antha R, Geethan RV. In vitro antioxidant and free radical scavenging activity of aqueous and ethanolic flower extract of Nymphaea alba. Int J Drug Dev Res. 2011;3(3):252-8.

70. Garba MH, Kabiru AY, Yusuf AM, Muhammad AH, Lekene BJ, Kabir M, Joseph A. In vivo trypanocidal activity of Nymphaea lotus Linn. Methanol extract against Trypanosoma brucei brucei. Asian Pac J Trop Dis. 2015;5(10): 808-12.

71. Bakr RO, Wasfi R, Swilam N, Sellam I. Characterization of the bioactive constituents of Nymphaea alba rhizomes and evaluation of anti-biofilm as well as antioxidant and cytotoxic properties. J Med Plants Res. 2016;10(26): 390-401.

\section{Publisher's Note}

Springer Nature remains neutral with regard to jurisdictional claims in published maps and institutional affiliations.

\section{Ready to submit your research? Choose BMC and benefit from:}

- fast, convenient online submission

- thorough peer review by experienced researchers in your field

- rapid publication on acceptance

- support for research data, including large and complex data types

- gold Open Access which fosters wider collaboration and increased citations

- maximum visibility for your research: over $100 \mathrm{M}$ website views per year

At BMC, research is always in progress.

Learn more biomedcentral.com/submissions 